INDEPENDENT JOURNAL OF MANAGEMENT \& PRODUCTION (IJM\&P)

http://www.ijmp.jor.br

v. 11, n. 7, November - December 2020

ISSN: 2236-269X

DOI: 10.14807/ijmp.v11i7.1137

\title{
INTEGRATING BALANCED SCORECARD AND HOSHIN KANRI A REVIEW OF APPROACHES
}

\author{
Rui Manuel Ferreira Dias \\ Faculdade de Ciências e Tecnologia, Universidade Nova de Lisboa, \\ Portugal \\ E-mail: rdias1263@hotmail.com
}

Alexandra Tenera

Faculdade de Ciências e Tecnologia, Universidade Nova de Lisboa,

Portugal

E-mail:abt@fct.unl.pt

Submission: 10/6/2019

Revision: $12 / 3 / 2019$

Accept: 1/30/2020

\section{ABSTRACT}

This paper discusses how companies can make their Strategic Thinking, Strategic Planning, and also discusses the integration of the Balanced Scorecard (BSC) and Hoshin Kanri (HK) approaches and then suggests and exemplifies an integrated model that could facilitate company's strategic deployment and implementation. A literature review of Balanced Scorecard and Hoshin Kanri conducted to provide a comprehensive understanding of each approach. The article discusses six integrated Balanced Scorecard / Hoshin Kanri models identified in the literature. The research work revealed differences and convergence points between Balanced Scorecard (BSC) and Hoshin Kanri (HK) approaches that the different integrated models intend to take advantage or reinforce in order to develop more robust methodologies. The study of different integration model, the difference between them and the know-how obtained in implementation and deployment of the strategy in the industry were crucial to develop the proposed model, which was conceived to overcome current identified models weaknesses. So, a new integrated framework was developed for Continuous Improvement organizations in order to leverage and combine Balanced Scorecard robustness and consistency for strategy development and Hoshin Kanri in order to added value in terms of short-term strategy, translating it to the everyday job activities, conceived and performed by all in turning of the Continuous Improvement strategy. 
DOI: 10.14807/ijmp.v11i7.1137

Keywords: trategic Planning, Strategic Deployment, Balanced Scorecard, Hoshin Kanri

\section{INTRODUCTION}

Strategic thinking should not be viewed as a formal planning process only (the classical strategic planning) but also as a process of discovery, innovation and creativity (strategic innovative thinking). In this way, organizations should obtain a fast, flexible and efficient response to everyday changes.

So, currently is not enough to know and understand the sector in which the organization operates, but also how to create new activities and new business opportunities in a systematic and sustainable way. If we start from this perspective, the strategy becomes not only a mere exercise of positioning and analysis, but also a process of discovery, in constant search of new patterns of interaction between clients, companies, technologies and markets that will require new supportive toolsets.

The strategy definition is one of the most critical tasks on business management, because defining a direction to be followed and having a sustainable market orientation and positioning is essential to organizations success, in which should be considered the knowledge of the external and the internal organization environment in order to make clear decisions about what the company should do and what should not to do in a long term.

Several strategic development systems are described in current literature (ARMISTEAD; PRITCHARD; MACHIN, 1999; DETTMER, 2003; YANG; YEHB, 2009; TOMA; MARINESCU, 2013) but in this paper we will address two of the most known ones namely: Balanced Scorecard (BSC) and Hoshin Kanri, both born and developed by the end of the last century and in next session synthesized and compared.

\section{THE BALANCED SCORECARD APPROACH}

Robert S. Kaplan, a professor at Harvard Business School and David P. Norton, president of Renaissance Solutions (KAPLAN; NORTON, 1992), first released balanced Scorecard (BSC) approach in 1992. Nowadays the Organization need clearly defined goals and strategies, in order to measure its business performance through quantifiable and verifiable indicators in a main strategic planning tool.

BSC can considered as a management system that enables companies to translate their strategic vision and deploy its strategic objective to the daily work of all employees. With BSC the underlying company's strategic logic is made explicit by a tool called strategic map (see 
Figure 1), where each objective is linked in a cause-and-effect chain, which associated indicators are related to the results planned in the strategy and the initiatives that should lead to this result, which logical links form the strategy hypothesis (KAPLAN; NORTON, 1996a; KAPLAN; NORTON, 2000a).

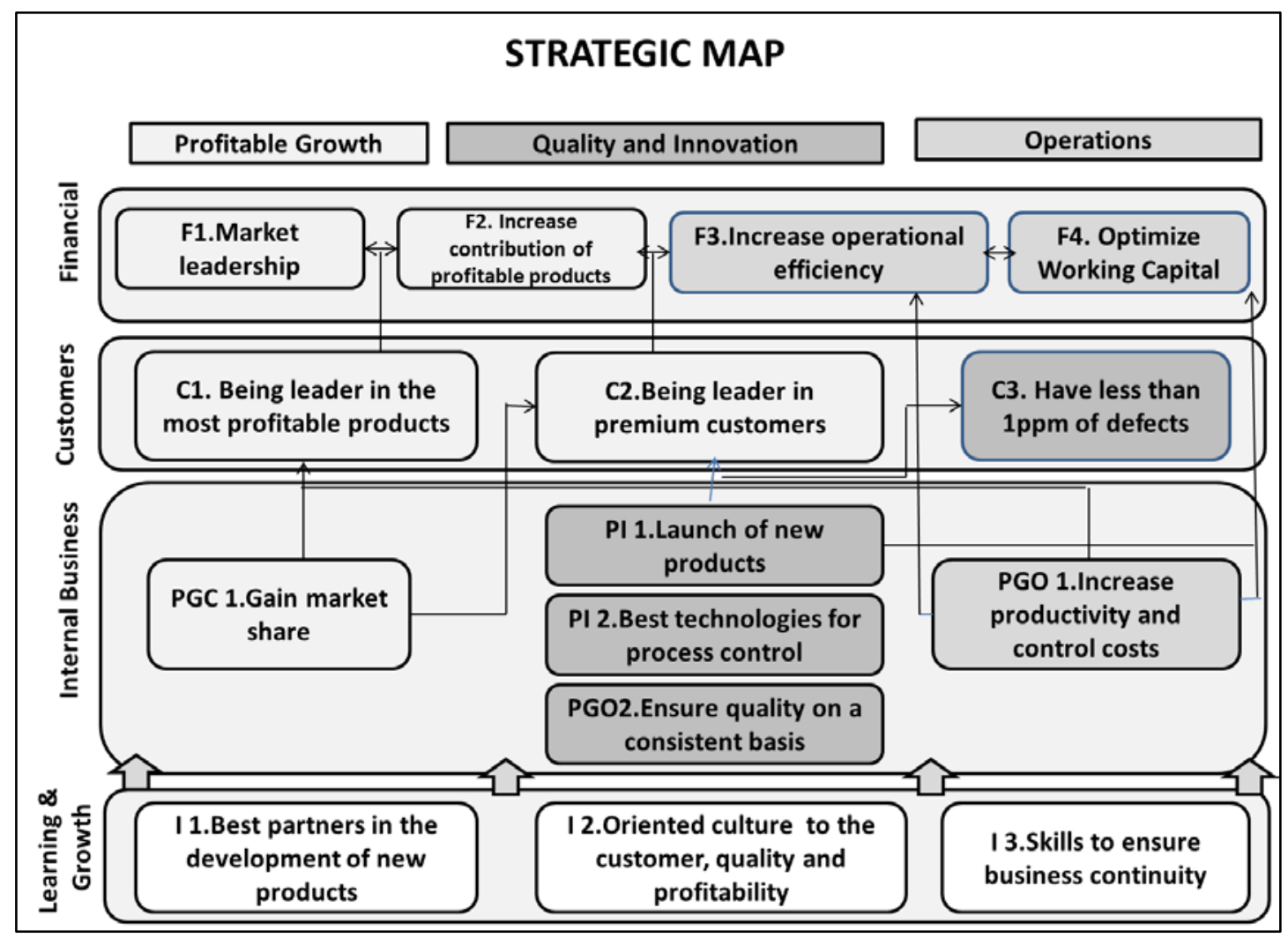

Figure1: Balanced Scorecard Strategic Map - example

As seen in Figure 1, the strategic objectives on the Balanced Scorecard usually focused through four main perspectives:

- Financial perspective;

- Customer perspective;

- Internal business perspective;

- Learning and growth perspective.

For each one of the strategic objectives identified from the strategic planning, company's indicators result and/or trend and targets, will indicate the established reach of the future situation, usually in a horizon of three to five years. After that, strategic initiatives or major projects that will lead to the achievement of the goals are then chosen. Thus, each strategic objective accompanied by the following components: strategic objective, measures, targets and initiatives (see Figure 2). 
DOI: 10.14807/ijmp.v11i7.1137

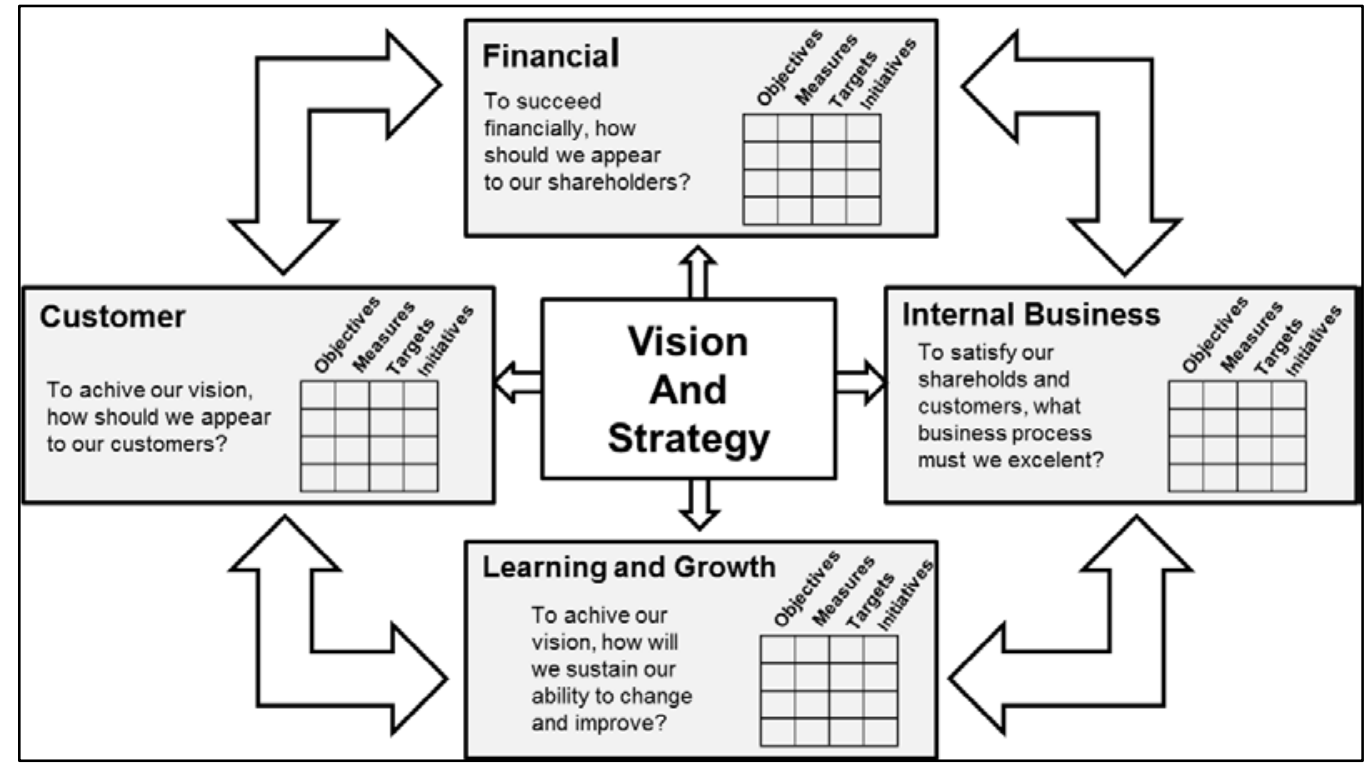

Figure 2: Balanced Scorecard Framework

Source: adapt from Kaplan and Norton (1996a, p.76)

In the last twenty years, a lot of academics and consultants have studied this methodology and contributed to its evolution. The studies and papers presented by the creators of the methodology (KAPLAN; NORTON, 1992; KAPLAN; NORTON, 1996a; KAPLAN; NORTON, 1996b; KAPLAN; NORTON, 2000a; KAPLAN; NORTON, 2001; KAPLAN; NORTON, 2004a; KAPLAN; NORTON, 2004b; KAPLAN; NORTON, 2006; KAPLAN; NORTON, 2007; KAPLAN; NORTON, 2008a; KAPLAN; NORTON, 2008b) were significant, fundamental and decisively contributed to its evolution from a Performance Measurement System to a Strategic Management System. 
ISSN: 2236-269X

DOI: 10.14807/ijmp.v11i7.1137

Table 1: Balanced Scorecard - Conceptual Evolution

\begin{tabular}{|c|c|c|}
\hline Authors & Year & Contributions \\
\hline $\begin{array}{l}\text { Simon, H. et al. } \\
\text { (1954) }\end{array}$ & 1954 & $\begin{array}{l}\text { Simon and his colleagues explored the role of financial and nonfinancial data to answering } \\
\text { three questions. } \\
\text { Are we doing good or bad? } \\
\text { What problems should we investigate? } \\
\text { The different ways of doing work, which one is best? } \\
\text { This study was perhaps the first to introduce the term "scorecard" in the discussion of } \\
\text { performance management. }\end{array}$ \\
\hline $\begin{array}{c}\text { Lewis } \\
\text { (Lewis, 1955) }\end{array}$ & 1955 & $\begin{array}{l}\text { In the 50's of the last century, a group of General Electric employees led a project to develop a } \\
\text { performance evaluation system in } 5 \text { decentralized GE business units. The project team } \\
\text { recommended that performance should be measured by one financial and seven non-financial } \\
\text { metrics. } \\
\text { 1.Rentability } \\
\text { 2. Market share } \\
\text { 3. Productivity } \\
\text { 4. Product Leadership } \\
\text { 5. Public Responsibility (legal and ethical behavior and responsibility of stakeholders, including } \\
\text { shareholders, suppliers, dealers, distributors and communities) } \\
\text { 6. People Development } \\
\text { 7. Employee Attitudes } \\
\text { 8. Balance between short and long range goals } \\
\text { Born there the roots for the creation of the Balance Scrorecard. }\end{array}$ \\
\hline $\begin{array}{l}\text { Johnson and Kaplan } \\
\text { (1987) }\end{array}$ & 1987 & $\begin{array}{l}\text { Johnson and Kaplan review the history of accounting management and conclude that US } \\
\text { companies have become obsessed with short-term financial measures and have failed to adapt } \\
\text { their accounting management and control systems to operational improvements stemming from } \\
\text { successful implementations of total quality management and cycle time management, which } \\
\text { appeared with the introduction of the new Japanese philosophies. }\end{array}$ \\
\hline $\begin{array}{l}\text { Kaplan and Norton } \\
\text { (Kaplan and Norton, } \\
\text { 1992) }\end{array}$ & 1992 & $\begin{array}{l}\text { Introduced the Balanced Scorecard in the Harvard Business Review. The BSC is described by a } \\
\text { Performance Measurement System. }\end{array}$ \\
\hline $\begin{array}{c}\text { Simons } \\
\text { (Simons, 1995) }\end{array}$ & 1995 & $\begin{array}{l}\text { Developed the Levers of Control management control framework. } \\
\text { Simons identified several types of management control systems that managers use to motivate, } \\
\text { monitor, and manage their strategies. The control systems included belief systems (mission, vision } \\
\text { and values), boundary systems, internal control systems, diagnostic systems, and interactive } \\
\text { systems. }\end{array}$ \\
\hline $\begin{array}{l}\text { Kaplan and Norton } \\
\text { (Kaplan and Norton, } \\
\text { 1996a) } \\
\text { (Kaplan and Norton, } \\
\text { 1996b) }\end{array}$ & 1996 & $\begin{array}{l}\text { Mobil US Marketing and Refining, Cigna Property and Casualty, and Chemical Retail Bank began } \\
\text { to adopt and used the scorecard to help them describe their strategies and implement a new } \\
\text { strategy management system based on scorecard measurements. The new insights helped Kaplan } \\
\text { and Norton to formulate the fundamental structure for a generic strategy management system. }\end{array}$ \\
\hline $\begin{array}{l}\text { Kaplan and Norton } \\
\text { (Kaplan and Norton, } \\
\text { 2001) }\end{array}$ & 2001 & $\begin{array}{l}\text { After studying the successful implementations of Mobil USM\&R and other early adopters Kaplan } \\
\text { and Norton proposed the following five leadership and management processes for successful } \\
\text { strategy execution, helping to create "the strategy-focused organization" } \\
\text { 1. Translate the strategy to operational terms; } \\
\text { 2. Align the organization to the strategy } \\
\text { 3. Make strategy everyone`s everyday job } \\
\text { 4. Make strategy a continual process } \\
\text { 5. Mobilize through executive leadership } \\
\text { This research completed the transformation of the Balanced Scorecard from a performance } \\
\text { measurement system to an interactive management system for strategy execution. }\end{array}$ \\
\hline
\end{tabular}


ISSN: 2236-269X

DOI: 10.14807/ijmp.v11i7.1137

\begin{tabular}{|c|c|c|}
\hline Authors & Year & Contributions \\
\hline $\begin{array}{l}\text { Kaplan and Norton } \\
\text { (Kaplan and Norton, } \\
\text { 2000a) (Kaplan and } \\
\text { Norton, 2001) } \\
\text { (Kaplan and Norton, } \\
\text { 2004a) (Kaplan and } \\
\text { Norton, 2004b) }\end{array}$ & 2000-2004 & $\begin{array}{l}\text { Born the idea of creating a strategy map from the Balanced Scorecard by linking the causal } \\
\text { relationship between the objectives and the necessary measures to obtained it. }\end{array}$ \\
\hline $\begin{array}{l}\text { Kaplan and Norton } \\
\text { (Kaplan and Norton, } \\
\text { 2006) }\end{array}$ & 2006 & $\begin{array}{l}\text { Kaplan and Norton showed how strategy maps and scorecards could articulate the role for a } \\
\text { corporate strategy that defined how to a collection of business units could create more value than } \\
\text { if each unit operated autonomously, as a stand-alone company. They discovered that all the } \\
\text { various corporate strategies for enhancing the value of their business units could be represented } \\
\text { using the four Balanced Scorecard perspectives }\end{array}$ \\
\hline $\begin{array}{l}\text { Pinho and Kaplan } \\
\text { (Pinho and Kaplan , } \\
\text { 2007) }\end{array}$ & 2007 & $\begin{array}{l}\text { Presented a Amanco case study who the Company utilized the Sustanaibility Scorecard with five } \\
\text { dimension diferent to the tradicional four dimension: Financial, Internal operation, Customers, } \\
\text { Inovation and learning and Environemental and social sustainability. This five prespectives } \\
\text { contribute to the achievement of the triple bottom line - social value, environmental value and } \\
\text { economic value. }\end{array}$ \\
\hline $\begin{array}{l}\text { Kaplan and Norton } \\
\text { (Kaplan and Norton, } \\
\text { 2008a) } \\
\text { (Kaplan and Norton, } \\
\text { 2008b) }\end{array}$ & 2008 & $\begin{array}{l}\text { Links strategic planning with operational execution throught the architecture of a comprehensive } \\
\text { six stage closed-loop management system: } \\
\text { 1. Develop the strategy } \\
\text { 2. Translate the strategy } \\
\text { 3. Align the organization } \\
\text { 4. Plan operations } \\
\text { 5. Monitor and learn } \\
\text { 6. Test and adapt the strategy } \\
\text { This development is about much more than just the Balanced Scorecard. It embeds the original } \\
\text { Balanced Scorecard framework as a component within a comprehensive management system that } \\
\text { integrates strategy and operations. }\end{array}$ \\
\hline Razek (2012) & 2012 & $\begin{array}{l}\text { Proposed a new model for BSC, which includes six perspectives: Financial, Clients; Internal } \\
\text { processes, Knowledge and Growth, Risk Management and Social Sustainability. This new } \\
\text { framework somehow fulfills one of the concerns presented by Kaplan, where the author expressed } \\
\text { the need for new developments of the tool to include Risk Management }\end{array}$ \\
\hline
\end{tabular}

Source: adapt from Kaplan, (2010) and Madsen and Stenheim (2015)

\section{HOSHIN KANRI}

Developed in Japan around 1960, in companies like Komatsu, Toyota and Sumitomo, Hoshin Kanri is based on American management by objectives methodology and continuous improvement cycle PDCA (Plan-Do-Check-Act) (AKAO, 1991; WITCHER; BUTTERWORTH, 1999) in which it was proposed to ensure the effective control of the company, so that the medium-and long-term strategies materialize in changes in the routines of day-to-day resulting in the improvement of processes and products (AKAO, 1991).

Hoshin Kanri is a systematic system of performance evaluation, developed to guide the day-to-day actions are aligned with the strategic vision of the company, so that they are effective and achieve the desired results (COWLEY; DOMB, 1997).

Hoshin Kanri is also viewed as a systematic and disciplined process developed to align, communicate and implement the strategy focused on deployed organizational key objectives in order to give an competitive advantage based on four main pillars (WITCHER; BUTTERWORTH, 1999; LEE; DALE,1999): 
DOI: 10.14807/ijmp.v11i7.1137

1. The entire organization is focused on vital strategic priorities, which are essential for Organizations sustainability;

2. Local plans and programs must be fully aligned with the Strategy;

3. Strategic plan is integrated with day-to-day management;

4. Systematic strategic progress review is required.

Ayano (1995) defines the Hoshin Kanri as being a systematic series of activities to achieve priority goals for improving quality and processes of the organization.

So, one of the Hoshin Kanri underlying requirements is that the deployment of the strategy needs to be done at all organizational levels, from management to operations. This development should be made through negotiation between the different organization levels (catchball), defining the intermediate goal that will fit each division or department. As advocated by Shigeru Mizuno (1998) Hoshin Kanri requires the participation of all employees at all levels.

According to the Hoshin Kanri approach, there are a few prerequisites that that must followed to ensure success and the robustness of this process as:

- Organizational Vision, Mission, and Values must be known and accepted;

- Identify in a long-term plan (Strategic Plan) the vital objectives to the organization which must be deployed in routine activities;

- Goals accepted after negotiation with team (catchball);

- Hierarchical and cross functional process definition;

- Establish metrics and measurements;

- Periodic review practices.

In the last years, many were those who study the Hoshin Kanri methodology and developed different frameworks to apply and implement this tool in the organizations, as synthetized in table 2, presented next. 
INDEPENDENT JOURNAL OF MANAGEMENT \& PRODUCTION (IJM\&P)

http://www.ijmp.jor.br

v. 11, n. 7, November - December 2020

ISSN: 2236-269X

DOI: 10.14807/ijmp.v11i7.1137

Table 2: Hoshin Kanri - An overview of most important implementation Models

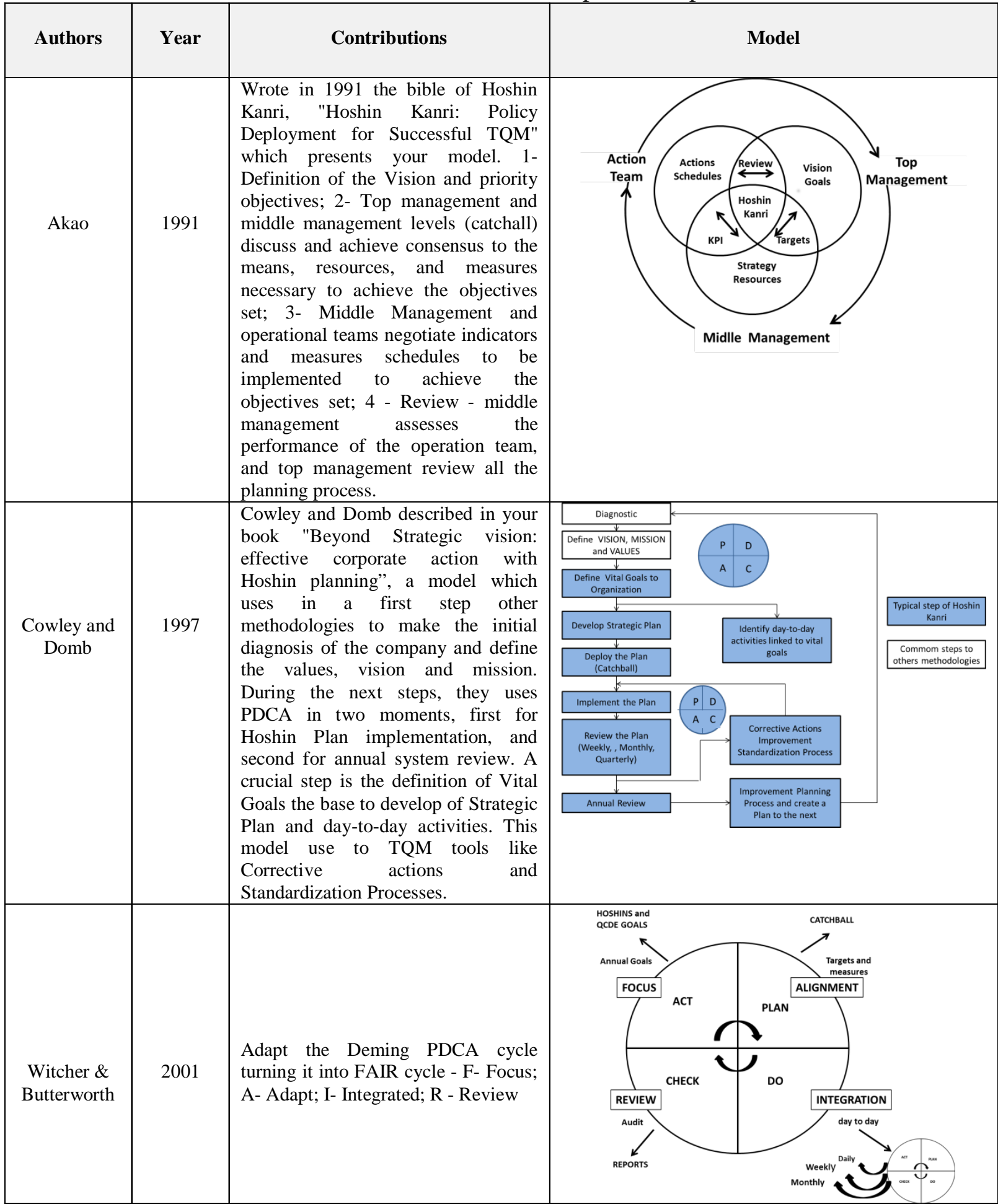


INDEPENDENT JOURNAL OF MANAGEMENT \& PRODUCTION (IJM\&P)

http://www.ijmp.jor.br

v. 11, n. 7, November - December 2020

ISSN: 2236-269X

DOI: 10.14807/ijmp.v11i7.1137

\begin{tabular}{|c|c|c|c|}
\hline Authors & Year & Contributions & Model \\
\hline Jackson & 2006 & $\begin{array}{l}\text { Author the book "Hoshin Kanri } \\
\text { for the Lean Enterprises ", who } \\
\text { presented a complete studies the } \\
\text { approaches combination of } \\
\text { Hoshin Kanri and Lean } \\
\text { Management, Jackson developed } \\
\text { a model with five steps that he } \\
\text { identified as SPDCA (Scan, Plan, } \\
\text { Do, Check, Act). The five steps } \\
\text { of the cycle are divided in seven } \\
\text { initiatives and supported by four } \\
\text { teams (Hoshin team, Tactical } \\
\text { team, Operational team and } \\
\text { Action team). To communicate } \\
\text { during the process of } \\
\text { development of Hoshin Kanri, } \\
\text { Jackson utilise the A3 tool. To } \\
\text { developed the annual Hoshin, } \\
\text { strategies of mid-term and to } \\
\text { deploy this to the operational and } \\
\text { action teams it create a new A3 } \\
\text { to which called X- Matrix }\end{array}$ & 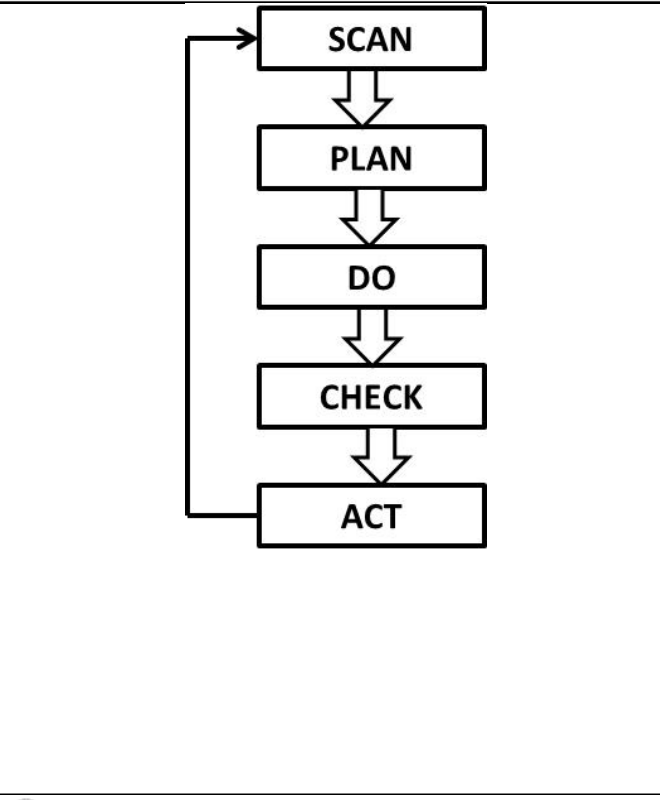 \\
\hline Hutchins & 2008 & $\begin{array}{l}\text { In your book " Hoshin Kanri: } \\
\text { The Strategic Approach to } \\
\text { Continuous Improvement } \\
\text { described a methodologies } \\
\text { applied in industrial environment } \\
\text { where the most relevant } \\
\text { characteristic is the number of } \\
\text { different management tools that } \\
\text { help in the implementation of } \\
\text { Hoshin Kanri. Tools like Six } \\
\text { Sigma, Quality Function } \\
\text { Deployment, Quality Systems, } \\
\text { Lean Manufacturing, Process } \\
\text { reengineering, Improvement } \\
\text { projects, Quality circles, Voice of } \\
\text { Customer, supply chain } \\
\text { management and SWOT. } \\
\text { According to the author Hoshin } \\
\text { Kanri methodologies enables } \\
\text { each implementation process is } \\
\text { unique to reflect the personality } \\
\text { of each organization. For } \\
\text { Hutchins the continuous } \\
\text { improvement philosophy of } \\
\text { Kaizen is the base of the success } \\
\text { of Hoshin Kanri. }\end{array}$ & 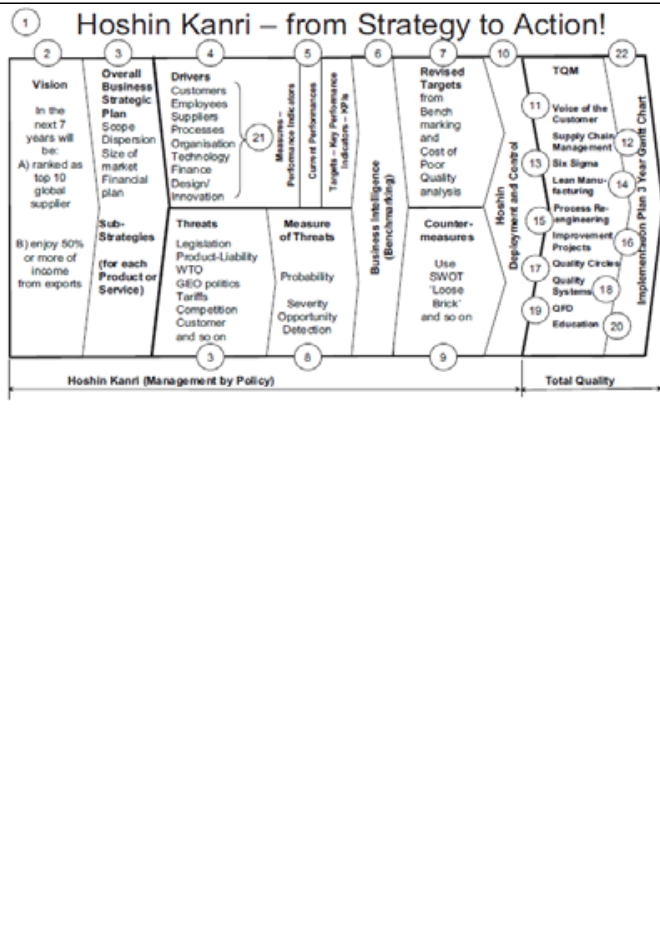 \\
\hline
\end{tabular}

\section{BALANCED SCORECARD vS HOSHIN KANRI}

The Balanced Scorecard and Hoshin Kanri are two analogous tools (TENNANT et al. 2002; WITCHER, 2003; ANDERSEN; LAWRIE; SAVIČ, 2004; MCCARTHY,2005), that aims to help improving the performance of organizations to align their strategies, objectives, targets and initiatives throughout the organization, however there are small differences between them as exposed. 
DOI: 10.14807/ijmp.v11i7.1137

The Balanced Scorecard is a performance-based approach that considers results very important. On the contrary, Hoshin Kanri is a process-based approach which concentrates not only on the results but also the means (or how) to reach them. In this respect, the Balanced Scorecard is perceived to be target-oriented and Hoshin Kanri as means-oriented (SERDAN; TANYAS, 2007).

Both systems have strengths and weakness, some literature presents the Balanced Scorecard as a non-participatory methodology, top-down (KANJI; SA, 2002) that can perfectly develop the strategy but has difficulty in communicating and implementing it (LOHMAN; FOURTUIN; WOUTERS, 2004); providing a strong conceptual framework for developing the strategy (KANJI; SA, 2002), but not presenting an implementation methodology (MALINA; SELTO, 2001).

On the other hand, Hoshin Kanri presents many difficulties in identifying the objectives that are vital for the organization and in presenting a structured model. Hoshin Kanri strongest contribution is catchall, the methodology for implementing the strategy for operational initiatives across the organization.

Thus, the Balanced Scorecard and Hoshin Kanri could be used perfectly in the Organization's strategic planning cycle with the following functions: Balanced Scorecard ensured that the strategy was translated, tested and monitored with long-term focus, while Hoshin Kanri would support the annual deployment and execution of priorities identified as strategic in the Balanced Scorecard.

So, the integration of the two methodologies can explore the best of each of them (see Table 3) and develop a system using the Balanced Scorecard for strategy development and Hoshin Kanri framework for strategy planning, communicating, implementing and documenting the strategy (SERDAN; TANYAS, 2007). 
INDEPENDENT JOURNAL OF MANAGEMENT \& PRODUCTION (IJM\&P)

http://www.ijmp.jor.br

v. 11, n. 7, November - December 2020

ISSN: 2236-269X

DOI: $10.14807 /$ ijmp.v11i7.1137

Table 3: BSC vs HK

Balanced Scorecard

Hoshin Kanri

\begin{tabular}{|c|c|c|}
\hline & Balanced Scorecard & Hoshin Kanri \\
\hline Focus & Vision, Mission, Strategy, objectives & Vision, Mission, Strategy, Vital Objectives \\
\hline Characteristic & Performance based & Process based \\
\hline Orientation & Target oriented & Means oriented \\
\hline $\begin{array}{l}\text { Translate de strategy into } \\
\text { operational terms }\end{array}$ & $\begin{array}{l}\text { Strategic map with objectives, indicators, } \\
\text { targets and iniciatives }\end{array}$ & $\begin{array}{l}\text { Deployment the annual vital objectives, with } \\
\text { indicators, targets and actions or mesuares }\end{array}$ \\
\hline $\begin{array}{l}\text { Align the Organization to the } \\
\text { strategy }\end{array}$ & $\begin{array}{l}\text { Deployment of the strategic map for all } \\
\text { departments, each department develop its } \\
\text { map aligned with the strategy }\end{array}$ & $\begin{array}{l}\text { Annual alignment through the deployment of } \\
\text { the measures or targets for units, showing } \\
\text { the role of each unit in the implementation of } \\
\text { Hoshin objective chosen by the organization }\end{array}$ \\
\hline $\begin{array}{l}\text { Make strategy everyone's } \\
\text { everyday job }\end{array}$ & $\begin{array}{l}\text { Communication of the strategy and allows the } \\
\text { creation of dashboards (Scorecards) } \\
\text { personal aligned with the strategy. }\end{array}$ & $\begin{array}{l}\text { Communicate in a structured way the } \\
\text { activities of each employee who are related to } \\
\text { the implementation of the Hoshin objective } \\
\text { and promotes the negotiation of goals and } \\
\text { individual actions by catch ball process; }\end{array}$ \\
\hline $\begin{array}{l}\text { Make strategy a continuous } \\
\text { process }\end{array}$ & $\begin{array}{l}\text { Encourages discussion and learning to the } \\
\text { strategy, and link the budget to the strategy } \\
\text { focusing resources on priority initiatives; }\end{array}$ & $\begin{array}{l}\text { Promotes discussion of objectives and goals, } \\
\text { so adding the contribution of all }\end{array}$ \\
\hline $\begin{array}{l}\text { Mobilize change through } \\
\text { executive leadership }\end{array}$ & $\begin{array}{l}\text { Successful of implementation the Balanced } \\
\text { Scorecard requires that management } \\
\text { demonstrate through their decisions and } \\
\text { priorities the new model focused on strategy }\end{array}$ & $\begin{array}{l}\text { Successful implementation of the Hoshin } \\
\text { Kanri requires that management has an } \\
\text { active role in all stages of deployment, until } \\
\text { the action plans for the teams are established }\end{array}$ \\
\hline Strength & Strutured conceptual framework & Catchball process, comunication \\
\hline Weakness & Top down, not participative & Hard to determine the vital few objectives \\
\hline
\end{tabular}

Source: Adapted from Kanji and Sa (2002) and Serdan and Tanyas (2007)

In fact, several authors have made proposals for the integration of these two strategic planning methodologies (REDI, 2003; YANG; YEHB, 2009; WITCHER; CHAU, 2007; SERDAN; TANYAS, 2007; ARBABSHIRANI; MUOSAKHANI, 2012; THOMAZ, 2015), following discussed in tables 4 to 9 .

Table 4: Redi's Corporative Model - BSC and HK

\begin{tabular}{|c|c|}
\hline Model & Corporative Model - BSC and HK \\
\hline Author $/$ Year & Renata Redi - 2003 \\
\hline \multicolumn{2}{|c|}{ Contributions } \\
\hline
\end{tabular}

This integrated model has three phases, long-term planning, short-term planning, and review to ensure a dynamics discussion of the chosen strategy. This integration comprises three organizational levels: corporate, unit and team. 
This model is draw according to the principles of the organization toward the strategy presented by Kaplan and Norton (2001).

- Translate the strategy into operational terms - development of Corporation Strategy map,

- Align the organization to the strategy - develop the unit strategic map aligned with the Corporate map with the Balanced Scorecard

- Make strategy everyone`s everyday job - apply Hoshin Kanri to select and deployment the vital few objectives (select for the Board) for all teams and integrate its in daily routines for operationalization of the strategy

- Make strategy a continuous process - the periodic evaluation of the strategic performance, its deployment and a cycle review of the strategic maps it`s the assurance that the process of development, planning, deployment of the strategy is an ongoing process.

- Mobilize change through executive leadership - the success of implementation of the model requires to senior management to lead a participatory process of negotiation to implementation the strategy in the organization.

This model has three steps

- Long-term planning - the aim of long-term planning phase is to translate the Corporation and Units strategy in a structured and synthetic form in objectives, indicators, targets and projects in order to facilitate their understanding, monitoring and evaluation, by senior management and teams.

- The long - term planning is doing with Balanced Scorecard.

- Short-term planning - the aim of this step is to bring the organization (Corporation and Units) to focus in annual objectives according to long-term planning. In this step the model select and communicate the vital few objectives, with the Catchball, define initiatives, project and targets and communicate to the teams

- Review - the model also contain a review step. This phase is very important and focus the organization in the strategy specially to make the strategy a continuous process.

\section{Model}

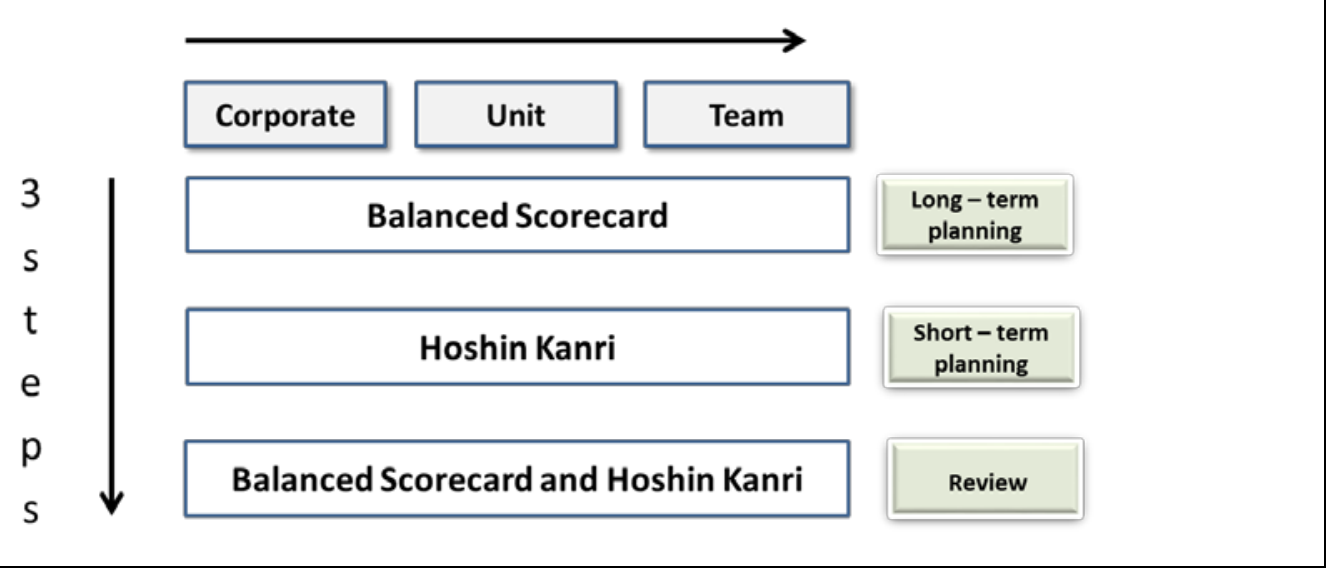

Source: Adapted from Redi (2003)

Table 5: BSC and HK with Fair model

\begin{tabular}{|c|c|}
\hline Model & Balanced Scorecard and Hoshin Kanri (with FAIR model) \\
\hline Author /Year & Barry J. Witcher e Vinh Sum Chau - 2007 \\
\hline \multicolumn{2}{|c|}{ Contributions } \\
\hline
\end{tabular}

The model integrate Balanced Scorecard, Hoshin Kanri and what authors call dynamic capabilities throughout the strategic management process. The model combines long and short-term activities of the organization into a framework so that strategic management can link top management goals with day-to-day goals.

Balanced Scorecard, core competences and dynamic capabilities needed to leverage business success used to make long-term strategic planning, on the other hand Hoshin Kanri to deploy and implement strategy in the short term.

The Hoshin Kanri, group this objectives in four perspectives, similar to Balanced Scorecard - Q - Quality; C - Cost; D - Delivery and $\mathbf{E}$ - education, which will be suitable as a basis for setting the annual priorities to deployment to all levels of organization. 
ISSN: 2236-269X

DOI: 10.14807/ijmp.v11i7.1137

The authors use the FAIR model (Focus, Alignment, Integration, and Review) for the deployment of the annual objectives grouped in QCDE.

The FAIR is an execution model of priorities in a descending sequence of four distinct phases:

\section{Focus}

The Senior Management team defines its priorities for the coming annual planning cycle. The priorities are based on the needs of the strategic themes and medium - term plans, and reflect the strengths and weaknesses in relation to the firm`s core capabilities.

\section{Alignment}

In this phase, called Catch ball is used to deploy the where the QCDE for all levels of the organization in an interactive way in order to building the targets and the necessary measures to achieve the objectives set.

\section{Integration}

The Hoshin and QCDE integrated in a form of daily management through of Deming Cycle - PDCA (Plan Do - Check - Act).

\section{Review}

The review phase of the FAIR model is the annual input to the global review of all planning strategic cycle. It is a senior level review of how the firm, as a whole, is managing its core capabilities.

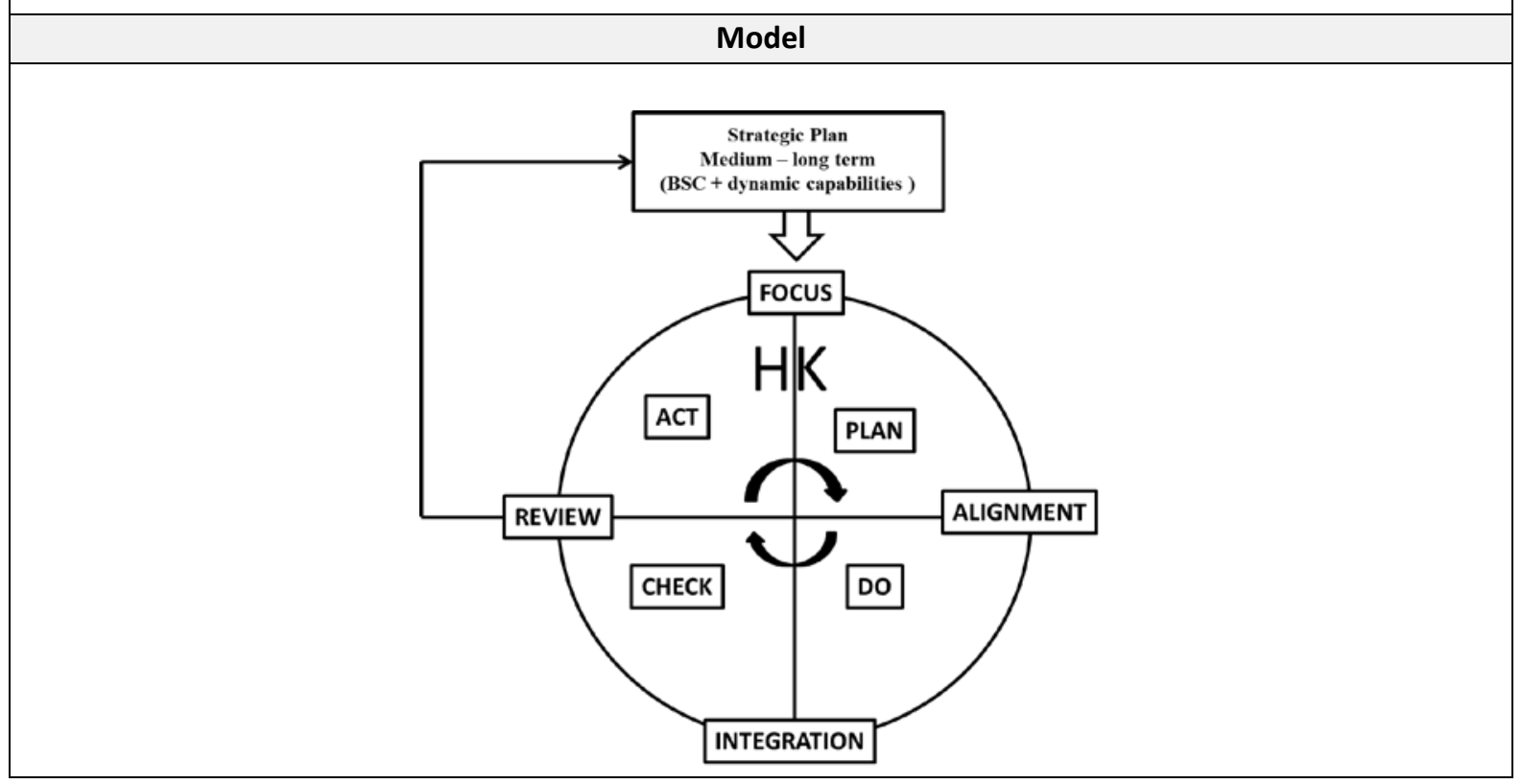

Source: adapted from Witcher and Chau (2007)

Table 6: HK and BSC for Strategic Management

\begin{tabular}{|c|c|}
\hline Model & Integrating Hoshin Kanri and the Balanced Scorecard for Strategic Management \\
\hline Author /Year & Seyda Serdan Asan eMehmet Tanyas - 2007 \\
\hline \multicolumn{2}{|c|}{ Contributions } \\
\hline
\end{tabular}

The model suggest an approach based in six steps, where Balanced Scorecard and Hoshin Kanri are integrated which focused on the vision and the deployment of strategies throughout the organization.

According to the authors, a combination between a performance-oriented approach like the Balanced Scorecard with a process-oriented approach like Hoshin Kanri creates synergy.

The model use the Balanced Scorecard to build a robust framework and a Hoshin Kanri for planning, implementation and documentation.

1. Preparation activities - this step involves environmental analysis, definition of mission, vision and the definition of strategic concepts: values, competencies, customers, products, market, competitors, resources, and processes;

2. Building the scorecard (the model use a BSC) - The scorecard construction should facilitate balancing the organization's strategy formulations into four perspectives;

3. Strategy map (the model use a BSC) - the strategy map is a visual draw of an organization`s strategies and represent the vital relationships among them that drive organizational performance; 
INDEPENDENT JOURNAL OF MANAGEMENT \& PRODUCTION (IJM\&P)

http://www.ijmp.jor.br

v. 11, n. 7, November - December 2020

ISSN: 2236-269X

DOI: 10.14807/ijmp.v11i7.1137

4. Deployments of strategies (the model use a HK) - the strategic objectives defined in the Balanced Scorecard are the vital few objectives to the Hoshin Kanri. These are the objectives to be deployed with the Catch ball tool;

5. Implementation of plans (the model use a HK) - target and means deployed at tactical level are the base for the developed implementation plans.

After the plans have been completely deployed down to implementation plans, they are rolled back, from bottom to top - catchball tool - to check inconsistencies, resource shortages and constraints;

6. Review (model use BSC and HK) - this step is crucial to do an evaluation of the performance of the planning cycle and it`s taken as the input for the next cycle.

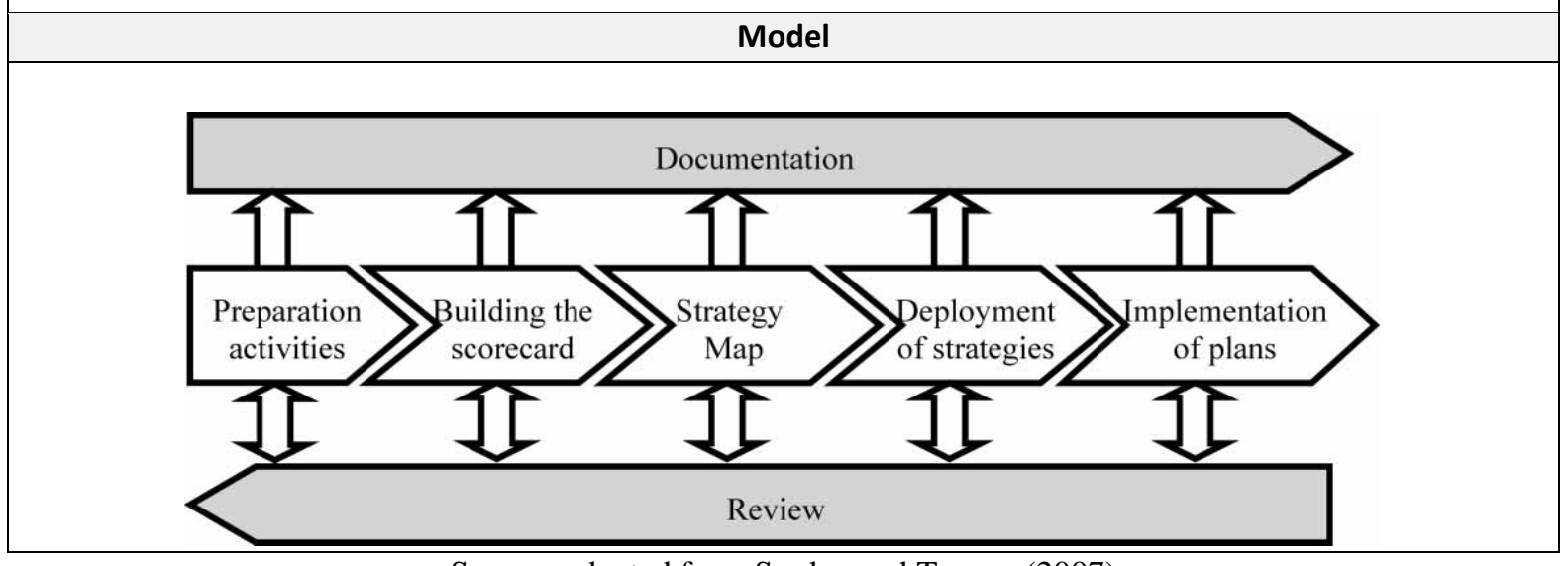

Source: adapted from Serdan and Tanyas (2007)

Table 7: Strategic planning, BSC and HK model

\begin{tabular}{|c|c|}
\hline Model & Integrated implementation model of strategic planning, BSC and Hoshin management \\
\hline Author /Year & Ching-Chow Yang e Tsu-Ming Yeh - 2009 \\
\hline \multicolumn{2}{|c|}{ Contributions } \\
\hline
\end{tabular}

The authors building your model based on the BSC model proposed by Kaplan and Norton (2004a).

1. Top management sets: Vision, Mission and Values, vital to define the orientation and the strategy;

2. Identify the KPIs and conceive the strategy;

It`s important for the success organization identify the vital KPIs in base on your core competences and yours Critical Success Factors (CSF) it will enhance its competitive advantage.

3. Strategic map - this the way to convert its various assets into desired outcomes. These desired outcomes measured by the KPI, which correspond to the strategies considered in the strategy map. (Kaplan \& Norton, 2000 b);

4. Scorecard - On developing its scorecard it is necessary to: (a)consider the cause-and-effect chain on the different items across four linked perspectives; (b) balance the lag indicators (profitability, market share and Customer retention) and lead indicators (performance drivers); and (c) identify the driving indicators (sometimes similar to lead indicators) and the derived indicators;

5. Department objectives, measures, target and KPI - deployment the strategy objectives to all organization utilizing the "Catchball” methodology of the Hoshin Kanri. The department objectives, measures, target and KPI should be aligned with the objectives of the Business Unit. Resources allocation and Action plan initiatives - departments and business units must therefore develop their action plans according to the organization's initiatives in a given department's area of responsibility.

6. Implementation - critical step of this model which needs to be monitored and controlled;

7. Review and evaluation (strategic outcomes) -periodic meeting for monitoring the implementation, but more effective is a quality audit used in Hoshin Management;

8. Annual Review - includes the following: (1) assessments of achievements and lessons learned in the past year; (2) identification of any gaps between targets; (3) recognition of any problems (and their root-cause analysis) in the implementation process; (4) identification of any changes in the environment; and (5) consideration of a future plan for the organization (Lee \& Dale, 1998).

\section{Model}


ISSN: 2236-269X

DOI: 10.14807/ijmp.v11i7.1137

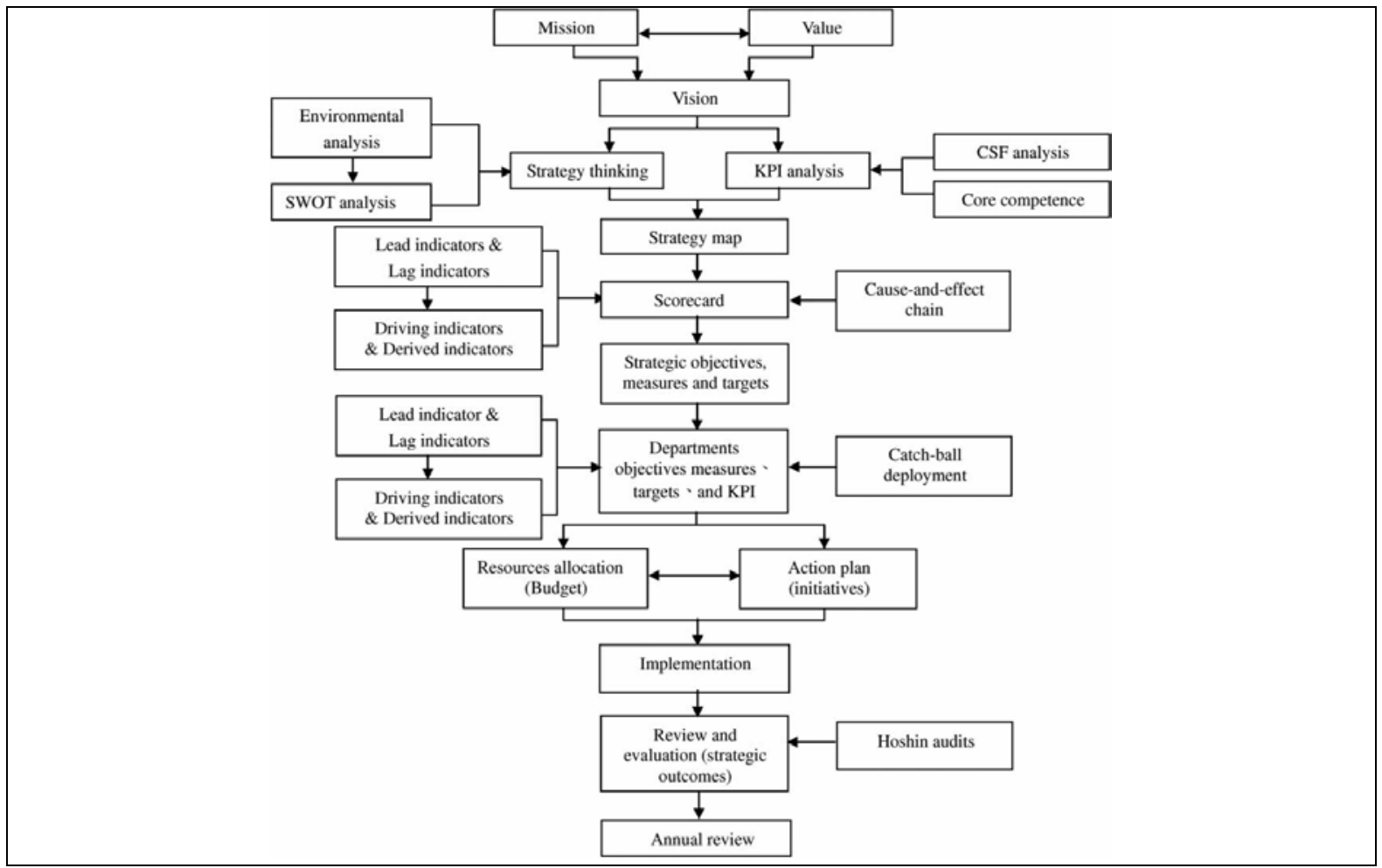

Source: adapted from Yang and Yehb (2009)

Table 8: BSC and HK model based on TQM

\begin{tabular}{|c|c|}
\hline Model & Incorporated model of Balanced Scorecard and Hoshin Kanri based on TQM \\
\hline Author /Year & Behrouz ArbabShirani e Hamid Reza Muosakhani - 2012 \\
\hline \multicolumn{2}{|c|}{ Contributions } \\
\hline
\end{tabular}

The model combining Balanced Scorecard and Hoshin Kanri, and propose a different balanced approach which try to eliminate some Balanced Scorecard weakness like insufficient organizational infrastructures; definition of quantitative indicators and the influence of each group of indicators in achieving objectives problems in order to assist companies to work and produce with better performance.

The model consists of main following elements:

- Identify of mission, core values \& vision of organization;

- Identify long term objectives \& strategies;

- Describe of operational objectives by Hoshin Kanri model;

- Transfer operational objectives to Balanced Scorecard model;

- Verify the strategies alignment with managerial and executive reviews;

- Continuous reflection of effectiveness of activities done by Hoshin Kanri model.

\section{Model}




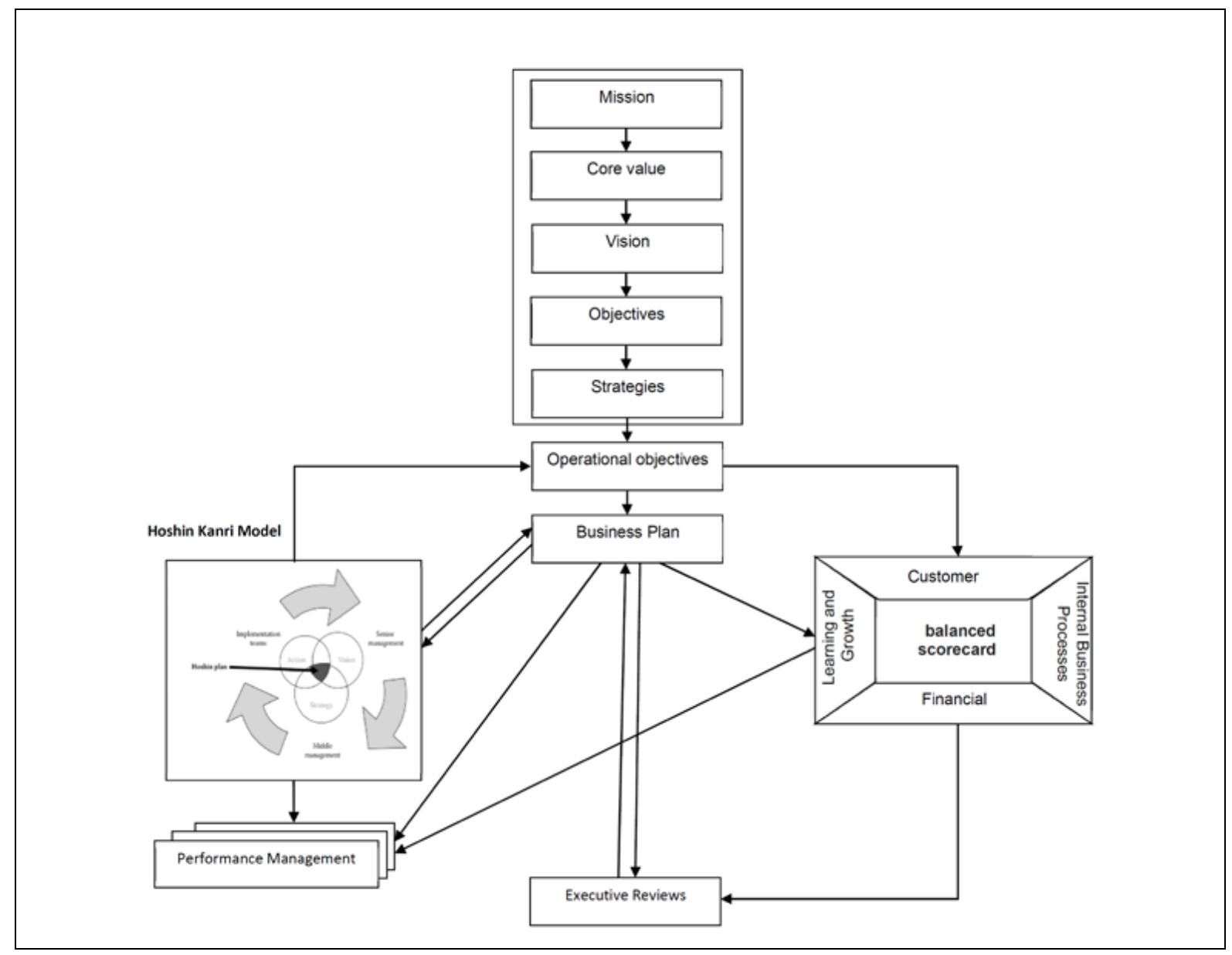

Source: adapted from ArbabShirani, Muosakhani (2012)

Table 9: Alignment and Strategy Deployment through the Integration of the BSC and HK

\begin{tabular}{|c|c|}
\hline Model & $\begin{array}{c}\text { Organizational Alignment and Strategy Deployment through the Integration of the } \\
\text { Balanced Scorecard and Hoshin Kanri }\end{array}$ \\
\hline Author /Year & Manuel Fernandes Thomaz - 2015 \\
\hline \multicolumn{2}{|c|}{ Contributions } \\
\hline
\end{tabular}

The author proposes a methodology which preparers the strategic plan and the definition of strategic objectives according to the Balanced Scorecard. Then the strategy deployed by Hoshin Kanri methodology through the implementation and action plans. After the implementation of the plans, the strategic planning cycle it moved back to the Balanced Scorecard to do the strategy review and preparing a new cycle.

\section{- Strategy}

Vision, Mission and Values are the conceptual base to do a Strategy. Strategic Plan and Strategic objectives defined with the Balanced Scorecard methodology.

To deployment the Strategy, Thomaz propose the Hoshin Kanri methodology, and adapt the FAIR model developed by Witcher and Butterworth (2001) and an implementation methodology similar to a proposed by Jackson (2006).

\section{- Focus}

The Strategic Objectives defined for the Balanced Scorecard is now the Vital Few Objectives fundamental to define the first level of the strategy.

To define this level of the strategy, the author recommended the creation a Hoshin team (top Management and first level Directors), and the utilization the X A3 Matrix, to start the discussion of the tactics and the improvement projects essential to achieve the strategies.

\section{- Alignment}

Department leaders, team leaders, operators, all employees who contribute to the organization's growth convert the Vital Few Objectives in work programs, implementation plans and daily activities.

The catchball is the tool for this step, to create a negotiation environment between all levels of organization in order to achieve a consensus deployment strategy in ambitious plans, but achievable. 
ISSN: 2236-269X

DOI: 10.14807/ijmp.v11i7.1137

The X A3 Matrix drawn in the Focus step is now deployment, through the catchball process.

- Integration

This is the integration of the strategy with the daily activities.

The outputs of this integration are the inputs to the review step.

\section{- Review}

The review step has now to do with the Balanced Scorecard approach, because the author thinks scorecard should ease the indicators and measures documentation, which are essential for the evaluation of the targets achievement defined for strategic objectives indicators.

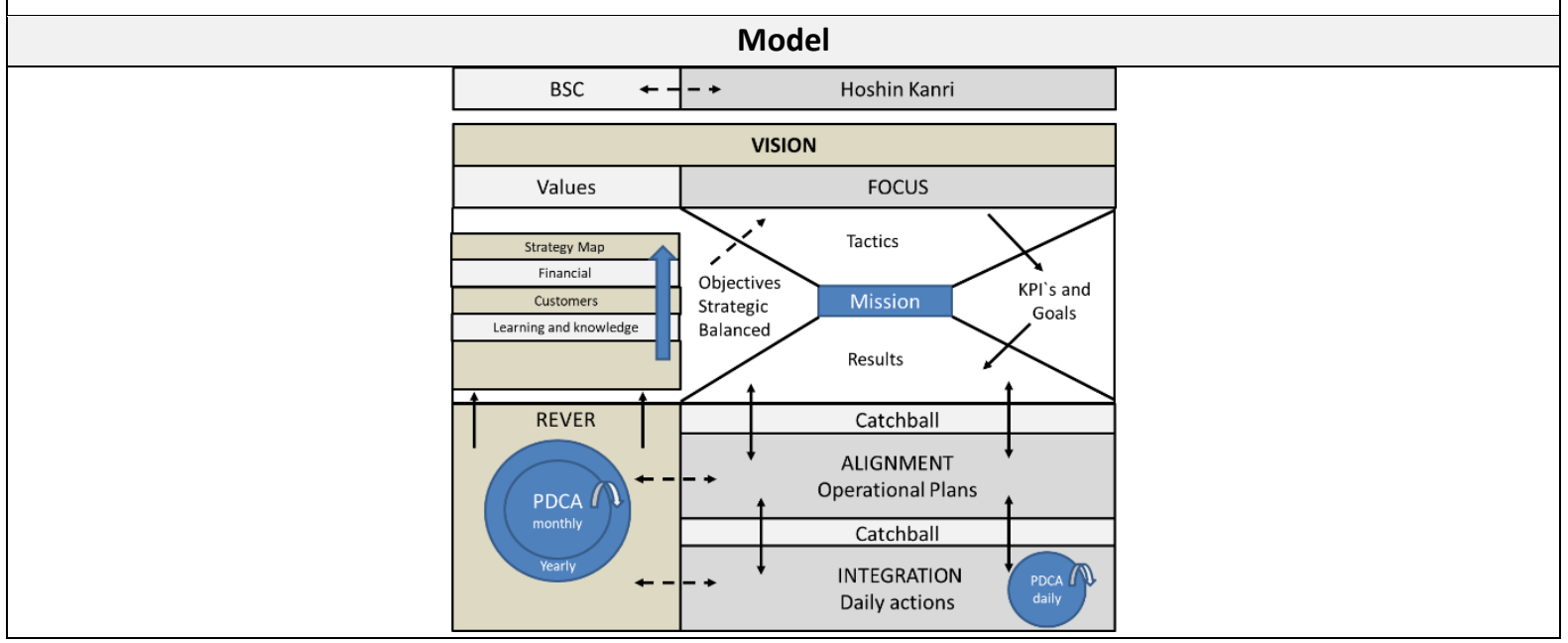

Source: adapted from Thomaz (2015)

All models presented justify their creation as a necessity to eliminate the weaknesses evidenced by both the Balanced Scorecard and Hoshin Kanri models mentioned above. As exposed, in the proposed models, most authors use the Balanced Scorecard for medium-long term strategy development and planning due to its robust structure and Hoshin Kanri for shortterm strategy deployment using one of its powerful tools. catchball, mentioned by all models described.

The only model that does not present this structure is the model developed by ArbabShirani and Muosakhani (2012). In this model and after having defined the strategic objectives by the Board, grouped in four perspectives of Hoshin Kanri and the Balanced Scorecard namely relating Q (quality) with Customers; C (cost) with Financial; D (delivery) with Internal Processes and E (education) with Learning and Growth, these go to the operation phase through the Hoshin Kanri structure and then pass to the Balanced Scorecard. The authors don `t clearly define the purpose for which this is done, as they do not give an objective reason.

Witcher and Chau (2007) and Yang and Yehb (2009) understand that the Organization's Core Competencies and Critical Success Factors are essential characteristics to keep in mind when developing the strategy so that the company can achieve success

The FAIR model (F-Focus; A-Alignment; I-Integration; R-Review) developed by Witcher and Butterworth (2001) is used in the integrated Balanced Scorecard/ Hoshin Kanri 
DOI: 10.14807/ijmp.v11i7.1137

models in the strategy deployment phase through Hoshin Kanri by Witcher and Chau (2007) and Thomaz (2015) with the aim of making this phase more systematized and more focused structures.

The models by ArbabShirani and Muosakhani (2012) and Thomaz (2015) recommend that the implementation of the measures necessary for the execution of the strategy be supported by improvement programs

Without reference to continuous improvement benchmarks, the Witcher and Chau (2007) model uses the PDCA (Plan, Do Check, Act) to operationalize its structure, as does Thomaz (2015). Thomaz (2015) for strategy deployment used, besides catchball, the X matrix developed by Jackson (2006), so that it`s made in a more structured and more visual way.

Renata Redi (2003) develops her model so that it can applied to large Organizations in which there are several business units with a corporate strategy that deployed to local strategies. Of all the models presented, only one clearly defines how to move from the medium-term strategic objectives to the vital objectives to deploy annually, Renata Redi (2003) indicate that this responsibility assigned to the Board, which can identify one or more strategic objectives to deployed annually.

On the other hand, Thomaz (2015) deployed all the medium and long-term objectives identified in the Balanced Scorecard and the result was a very heavy system that was difficult to operate and to monitor.

\section{A STRATEGIC DEPLOYMENT WITH BSC AND HK - A CONCEPTUAL FRAMEWORK PROPOSAL}

In order to help organizations whose Strategic Thinking is Continuous Improvement oriented, an integrated BSC and HK framework is next proposed and detailed

So, in order to establish and operationalize Continuous Improvement Strategic Planning the classical logic of Balanced Scorecard will proposed supported by Hoshin Kanri methodology and catchball cycles involving all organizational classical levels on and Hybrid Framework (see Figure 4) in which:

The revision of state of art about integration of Balanced Scorecard and Hoshin Kanri detected a recurring difficulty in all the evaluated frameworks: as from the Balanced Scorecard objectives (long-term strategies), determine the vital objectives, which will be the subject of short-term strategies that will be part of the daily activities of organizations. 
DOI: 10.14807/ijmp.v11i7.1137

To make this work more objective and easier is possible using tools to help in prioritizing the objectives set by long-term strategy in the vital objectives for one year.

- Strategic thinking: this task will be the only responsibility of senior management, where we are, where we want to go and how we go, having nothing tactical or operational.

At this stage, the company`s Values, its Mission and Vision are defined or reviewed establishing the company's competitive advantages, which will differentiate it from its competitors.

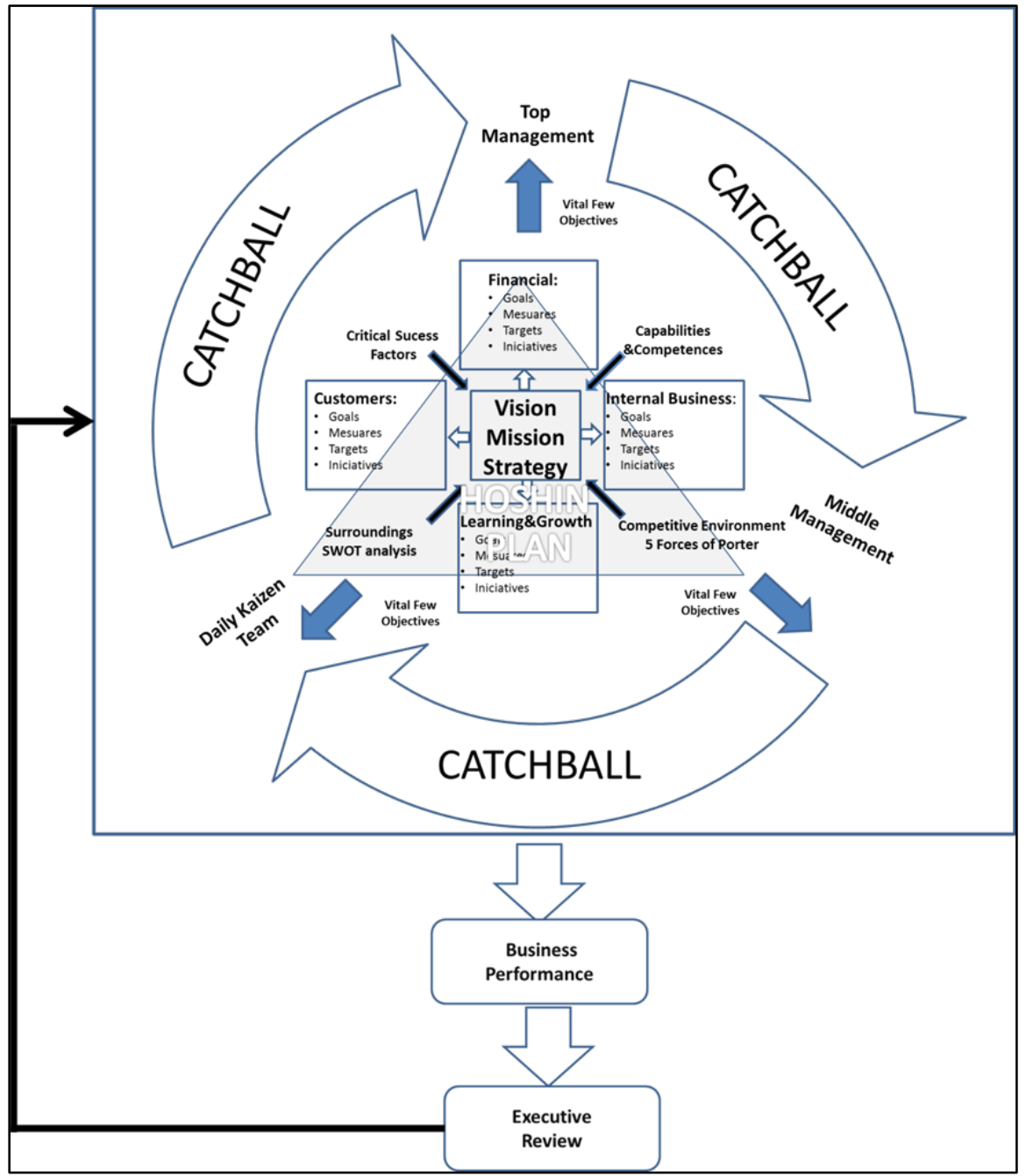

Figure 4: Integrating BSC and HK to Strategic Thinking and Strategic planning a hybrid framework

To support the Strategic thinking process, following aspects must considered:

- Surroundings analyses - SWOT analysis (Strengths, Weaknesses, Opportunities, Threats); 
DOI: 10.14807/ijmp.v11i7.1137

- Competitive Context characterization - considering the Porter's 5 main forces (Competitors, Suppliers, Customers, Substitute products, New entries);

- Capabilities \& Competences identification and characterization;

- Critical Success Factors identification and characterization.

- Strategic Planning: this task will be the strategic thinking operationalization based on the Balanced Scorecard methodology. For each of the four classical pillars (Financial, Costumers, Internal Business and Learning \& Growth), Top Management and Middle Management will define objectives, measures, targets and initiatives, for a period of three five years.

- Hoshin Planning: from the BSC using a priority matrix, Vital Few Objectives and correspondent`s measures and target are selected, to be deployed to current year.

- Organization define the essential criteria, the weight of each them (for example):

$\checkmark$ rapid achievement;

$\checkmark$ financial impact vs investment;

$\checkmark \quad$ low resource requirements (human or financial);

$\checkmark$ precedence over other objectives;

$\checkmark$ degree of importance for the final implementation of the Strategy.

And apply de priority matrix to define de vital few objectives to deployed for the current year.

For each vital few objective, we define a: measures, targets and initiatives using a Catchball methodology.

To deploy, operationalize and monitoring the vital few objectives for all level of organization, we use an X Matrix (JACKSON, 2006).

Quality, Lean, TOC (Theory of Constraints) and Six-Sigma tools can also be used to support the short-term operationalization of the strategy (see Table 11)

Execution of these activities should be aligned with long-term strategy, must have the support of everyone, especially middle managers and shop floor employees, organized in Kaizen teams, which implement, analyze and monitor the day-to-day activities. This exercise repeated annually after a review of the work done and the results obtained. 
- Catchball: This activity will be essential for the involvement, deployment and monitoring of the strategy throughout the organization because it follows the entire cycle from thinking the strategy, planning, implement, analyze the strategy performance and it`s review.

- Review of Business Performance: In defined periods, the resulting implementation performance of the strategy must be audit and evaluated at various levels of the organization. The day-to-day execution performance resulting will be evaluated in a weekly audit of each Kaizen teams, which evaluates the performance of the KPIs defined for each team, analyze deviations, identify the causes and promote the necessary corrective actions if needed.

The Hoshin audits information results will analyzed in monthly audit meetings between the Manager of Departments and Top Management. According to the performance of each, one suggested a corrective action plan to correct the deviations.

The Board meets quarterly. At each of these board meetings, it reviews one of four strategic pillars, the degree of team involvement, the implementation of the annual plan, deviations, and corrective actions proposed by the teams. (see Table 10)

- Executive Review: The board should meet every year in order to analyze, in detail, every pillar of the strategy.

For this meeting there are some inputs like:

o Level of objectives, measures and initiatives implemented;

o Results of different Hoshin audits;

o Level of resources (people, equipment and facilities) performance;

o KPI`s results;

o Business performance;

o In addition, some outputs like level of achievement of the strategy and next annual cycle needs.

- New annual cycle: Coming to the end of annual cycle is necessary to prepare a new cycle. In order to help preparing the new cycle the following supporting documents can be used:

o Company`s Executive Border Report of the review; 
INDEPENDENT JOURNAL OF MANAGEMENT \& PRODUCTION (IJM\&P)

http://www.ijmp.jor.br

v. 11, n. 7, November - December 2020

ISSN: 2236-269X

DOI: 10.14807/ijmp.v11i7.1137

o Long-term strategic planning (according with the four pillars of the Balanced Scorecard);

o Hoshin Plan of the previous cycle.

During the preparation of the new Hoshin plan, the three essential requirements shouldn't forgotten:
$\checkmark$ be aligned with long-term plan;
$\checkmark$ covering all the Organizational vital few objectives;
$\checkmark$ be directed to the Company's day-to-day activities.

For the preparation of the new cycle, the Catchball approach to collect inputs from all levels of the organization is used again.

Table 10: Integrating BSC and HK in the proposed model

\begin{tabular}{|c|c|c|c|c|}
\hline PDCA & Operation & Tools and Documents & Who & When \\
\hline \multirow{4}{*}{ PLAN } & $\begin{array}{l}\text { Strategic Thinking, } \\
\text { Vision and Mission }\end{array}$ & $\begin{array}{ll} & 5 \text { Forces of Porter } \\
\text { - } & \text { SWOT } \\
\text { - } & \text { Critical Success Factors } \\
\text { - } & \text { Capabilities and Competences } \\
& \text { Revision Document }\end{array}$ & - $\quad$ Top Management & Every three years \\
\hline & $\begin{array}{l}\text { Strategic Planning } \\
\quad \text { (long-term) }\end{array}$ & $\begin{array}{ll}\text { - } & \text { Balanced Scorecard } \\
\text { - } & \text { Catchball }\end{array}$ & $\begin{array}{ll}\text { - } & \text { Top Management } \\
\text { - } & \text { Middle } \\
\text { Management }\end{array}$ & Every three years \\
\hline & $\begin{array}{l}\text { Short-term } \\
\text { operating strategy } \\
\text { (one year) }\end{array}$ & $\begin{array}{ll}\text { - } & \text { Thinking Process (TOC) } \\
\text { - } & \text { Hoshin Kanri - X Matrix } \\
\text { - } & \text { Catchball } \\
\end{array}$ & $\begin{array}{ll}\text { - } & \text { Top Management } \\
\text { - } & \text { Middle } \\
& \text { Management } \\
\text { - } & \text { Kaizen Team } \\
\end{array}$ & Every year \\
\hline & $\begin{array}{l}\text { Definition of KPI, } \\
\text { targets and } \\
\text { initiatives } \\
\end{array}$ & $\begin{array}{ll}\text { - } & \text { Hoshin Kanri - X Matrix } \\
\text { - } & \text { Catchball }\end{array}$ & $\begin{array}{ll}- & \text { Middle } \\
& \text { Management } \\
\text { - } & \text { Kaizen Team } \\
\end{array}$ & Every year \\
\hline DO & $\begin{array}{l}\text { Hoshin Plan } \\
\text { Implementation }\end{array}$ & $\begin{array}{ll}\text { - } & \text { Quality Tools } \\
\text { - } & \text { Theory of Constraints Tools } \\
\text { - } & \text { Lean Tools } \\
\text { - } & \text { Six Sigma Tools } \\
\end{array}$ & $\begin{array}{l}\text { Middle } \\
\text { Management } \\
\text { Kaizen Team } \\
\end{array}$ & Daily \\
\hline \multirow[t]{2}{*}{ CHECK } & $\begin{array}{l}\text { Review of Business } \\
\text { Performance }\end{array}$ & $\begin{array}{l}\text { - } \quad \text { Hoshin Audit } \\
\text { - } \text { Middle Management Audit } \\
\text { meeting } \\
\text { Top Management Audit } \\
\text { meeting (one pillar of BSC) }\end{array}$ & $\begin{array}{l}\text { Daily Kaizen } \\
\text { Manager } \\
\text { - } \quad \text { Executive } \\
\text { committee } \\
\text { - Board }\end{array}$ & $\begin{array}{ll}\text { - } & \text { Weekly } \\
\text { - } & \text { Monthly } \\
\text { - } & \text { Every } \\
\text { three } \\
\text { months }\end{array}$ \\
\hline & Executive Review & $\begin{array}{l}\text { - Top Management Audit ( all } \\
\text { pillar of BSC, ) }\end{array}$ & - $\quad$ Board & Every year \\
\hline ACT & New Annual Cycle & - Documents of revisions & - $\quad$ Top Management & Every year \\
\hline
\end{tabular}


DOI: 10.14807/ijmp.v11i7.1137

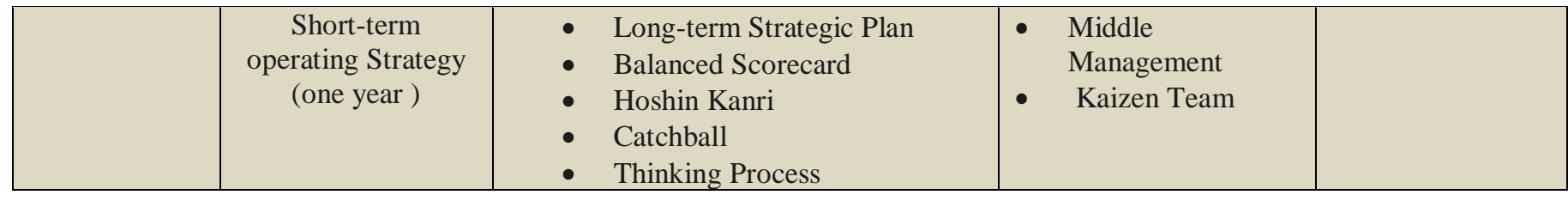

In order to help the implementation of Hoshin Plan we present next a table 11 with some tools who can used during the day-to-day activities.

Table 11: Hoshin Plan - package of some tools to help implementation

\begin{tabular}{|c|c|c|c|c|}
\hline & Quality & TOC & Lean & Six Sigma \\
\hline $\begin{array}{l}\text { Defining a } \\
\text { problem, } \\
\text { improvement } \\
\text { opportunity, or } \\
\text { requirements }\end{array}$ & $\begin{array}{ll}\text { - } & \text { Quality } \\
\text { Function } \\
\text { Deployment } \\
\text { (QFD) } \\
\text { - } \quad \text { Ishikawa } \\
\text { diagram }\end{array}$ & - $\quad$ Thinking Process & - $\quad \mathrm{VSM}$ & $\begin{array}{l}\text { - } \text { Project Charter } \\
\text { - } \quad \text { Voice of the } \\
\text { Costumer }\end{array}$ \\
\hline $\begin{array}{l}\text { Measuring } \\
\text { Process } \\
\text { performance }\end{array}$ & $\begin{array}{ll}\text { - } & \text { Pareto Chart } \\
\text { - } & \text { Histogram } \\
\text { - } & \text { Scatter } \\
& \text { Diagram }\end{array}$ & & - $\mathrm{OEE}$ & $\begin{array}{ll}\text { - } & \text { Process Map } \\
\text { - } & \text { Capability } \\
& \text { Analyses }\end{array}$ \\
\hline $\begin{array}{l}\text { Analyzing } \\
\text { processes to } \\
\text { determine root } \\
\text { causes of } \\
\text { variation, defects } \\
\text { or poor } \\
\text { performance }\end{array}$ & $\begin{array}{l}\text { Failure Mode } \\
\text { and Effects } \\
\text { analysis }\end{array}$ & & $\begin{array}{ll}-\quad 3 \mathrm{C} \\
-\quad 5 \mathrm{~W}\end{array}$ & $\begin{array}{ll}\text { - } & \text { Root Cause } \\
& \text { analysis } \\
\text { - } & \text { Multi Var Charts }\end{array}$ \\
\hline $\begin{array}{l}\text { Improving } \\
\text { process } \\
\text { performance by } \\
\text { addressing root } \\
\text { causes }\end{array}$ & & $\begin{array}{ll}\text { - } & \text { Five Focusing } \\
\text { Steps } \\
\text { - } \quad \text { Throughput } \\
\text { Accounting } \\
\end{array}$ & $\begin{array}{ll}\text { - } & \text { Kaizen events } \\
\text { - } & \text { SMED }\end{array}$ & $\begin{array}{l}\text { - Design of } \\
\text { Experiences }\end{array}$ \\
\hline $\begin{array}{l}\text { Controlling } \\
\text { process and future } \\
\text { performance }\end{array}$ & & & $\begin{array}{ll}\text { - } & 5 S \\
\text { - } & \text { Poka-yoke } \\
\text { - } & \text { Standard Work } \\
\text { - } & \text { Visual } \\
& \text { Management } \\
\text { - } & \text { Daily Kaizen } \\
\end{array}$ & $\begin{array}{l}\text { - Control Plan } \\
\text { Statistic Control } \\
\text { Process }\end{array}$ \\
\hline $\begin{array}{l}\text { Controlling } \\
\text { Working - } \\
\text { Process } \\
\end{array}$ & & $\begin{array}{l}\text { Drum-Buffer-Rope } \\
\text { (DBR) }\end{array}$ & - Kanban & \\
\hline Others & $\begin{array}{ll}\text { - } & \text { Flow Charts } \\
\text { - } & \text { Brainstorming } \\
\text { - } & \text { Check Sheet } \\
\end{array}$ & & & \\
\hline
\end{tabular}

\section{MAIN CONCLUSION}

For companies to remain competitive in today's globalized marketplace, it is essential to ensure proper strategy planning and implementation.

This should reflect the Organization's mission and vision, the surrounding environment, the wishes of its shareholders and the involvement of all employees. 
Balanced Scorecard and Hoshin Kanri both are used to perform this task. However, the different applications of each methodology in various organizations and in different contexts have shown some weaknesses. Integration may be a response to overcome the weaknesses found when they applied separately.

The integrated framework presented attempts to leverage and combine the best of each approach: BSC as a robust and consistent approach to developing strategies and defining its long-term objectives, indicators, initiatives, and Hoshin Kanri for deployment and implementation of the strategy in the daily activity.

The developed framework differs from existing models by presenting a tool for prioritizing strategic objectives (priority matrix) to be implemented annually as well utilizing continuous improvement tools, namely Quality, TOC, Lean and Six Sigma to help implementation and monitoring the strategy in day-to-day activities.

In a Continuous Improvement context, the integration of these two approaches in the proposed hybrid model supports the involvement of the entire organization from top management to the GEMBA, making strategy a working shared effort.

\section{REFERENCES}

AKAO, Y. (1991) Hoshin Kanri: Policy Deployment for Successful TQM, Productivity Press Inc., Cambridge.

ANDERSEN, H. V.; LAWRIE, G.; SAVIČ, N. (2004) Effective quality management through third-generation Balanced Scorecard, International Journal of Productivity and Performance Management, v. 53, n. 7, p. 634-645. DOI: 10.1108/17410400410561259

ARBABSHIRANI, B.; MUOSAKHANI, H. R. (2012) Proposing an Incorporated model of Balanced Scorecard and Hoshin Kanri based on TQM (Case Study: MSC). Proceedings of the 2012 International Conference on Industrial Engineering and Operations Management. Istanbul, Turkey, p. 1322-1329.

ARMISTEAD, C. PRITCHARD, J.-P.; MACHIN, S. (1999) Strategic business process management for organizational effectiveness, Long Range Planning, v. 32, n. 1, p. 96-106.

AYANO, K. (1995) Estratégias para promover o TQM, Fundação Vanzolini, São Paulo.

COWLEY, M.; DOMB, E. (1997) Beyond Strategic vision: effective corporate action with Hoshin planning, Butterworth-Heinemanm, Newton, USA.

DETTMER, H. W. (2003) Strategic Navigation - The Constraint Management Model.

Proceeding of the APICS International Conference Las Vegas, Nevada, USA

HUTCHINS, D. (2008) Hoshin Kanri. The Strategic Aproach to Continuous Improvement, Hampshire, Grover.

JACKSON, T. L. (2006) Hoshin Kanri for Lean Enterprise: Developing Competitive Capabilities and Managing Profit, Productivity Press, New York. 
KANJI, G. K.; SA, P. M. (2002) Kanji’s business scorecard, Total Quality Management, v. 13, n. 1, p. 13-27.

KAPLAN, R. S.; NORTON, D. P. (1992) The Balanced Scorecard: measures that drive performance, Harvard Business Review, v. 70, n. 1, p. 71-79.

KAPLAN, R. S.; NORTON, D. P. (1996a) The BSC: Translating Strategy into Action, Harvard Business School Press, Boston, Massachusetts.

KAPLAN, R. S.; NORTON, D. P. (1996b) Using the Balanced Scorecard as a Strategic Management System, Harvard Business Review (January-February), p. 75-85.

KAPLAN, R. S.; NORTON, D. P. (2000a) The Strategy - Focused Organization: How BSC Companies Thrives in the New Business Environment - BSC to Work, Harvard Business School Press, Boston, Massachusetts.

KAPLAN, R. S.; NORTON, D. P. (2000b) Having trouble with your strategy? Then map it. Harvard Business Review, v. 78, n. 5, p. 167-176.

KAPLAN, R. S.; NORTON, D. P. (2001) The Strategy-Focused Organization: How Balanced Scorecard Companies Thrives in the New Competitive Environment, HBS Press, Boston.

KAPLAN, R. S.; NORTON, D. P. (2004a) Strategy Maps: Converting Intangible Assets into Tangible Outcomes, HBS Press, Boston.

KAPLAN, R. S.; NORTON, D. P. (2004 b) Measuring the Strategic Readiness of Intangible Assets, Harvard Business Review (February), p. 52-63.

KAPLAN, R. S.; NORTON, D. P. (2006) Alignment: Using the Balanced Scorecard to Create Corporate Synergies, HBS Press, Boston.

KAPLAN, R. S.; NORTON, D. P. (2008a) Mastering the Management System, Harvard Business Review (January), p. 62-57.

KAPLAN, R. S.; NORTON, D. P. (2008b) The Execution Premium: Linking Strategy to Operations for Competitive Advantage, HBS Press, Boston.

KAPLAN, R. S. (2010) The Conceptual Foundation of the Balanced Scorecard. Harvard Business School Accounting \& Management Unit, working paper n. 10-074,

LEE, R.; DALE, B. (1998) Policy deployment: An examination of the theory. International Journal of Quality \& Reliability Management, v. 15, n. 5, p. 520-534.

LEE, R.; DALE, B. (1999) Managing Quality, London Prentice-Hall, London.

LOHMAN, C.; FOURTUIN, L.; WOUTERS, M. (2004) Designing a performance measurement system: a case study, European Journal of Operational Research, v. 156, n. 2, p. 267-286.

MADSEN, D.; STENHEIM, T. (2015) The Balanced Scorecard: A review of Five Research Areas, American Journal of Management, v. 15, n. 2, p. 24-41.

MALINA, M.; SELTO, F. (2001) Communicating and controlling strategy: an empirical study of the effectiveness of the Balanced Scorecard, Journal of Management Accounting Research, v. 13, p. 47-90.

MCCARTHY, G. (2005) Leadership practices in German and UK organizations, Journal of European Industrial Training, v. 29, n. 3, p. 217-23. 
MIZUNO, S. (1998) Company Wide Total Quality Control. Asian Productivity Organization, Tokio.

PINHO, R. R. D.; KAPLAN, R. S. (2007) Amanco: Developing the Sustainability Scorecard, case study 9-107-038, Harvard Business School Publishing, Boston.

REDI, R. (2003) Modelo de implementação da estratégia através do uso integrado do Balanced Scorecard e do Gerenciamento pelas Directrizes.Master Thesis in Production Engenering - Pós - Graduation Program.Universidade Federal de Santa Catarina.

Florianópolis, p.185.

SERDAN, S. A.; TANYAS, M. (2007) Integrating Hoshin Kanri and the Balanced Scorecard for Strategic Management: The Case of Higher Education. Total Quality Management, v. 18, n. 9, p. 999-1014.

SIMON, R. (1995) Levers of Control: How Managers Use Innovative Control Systems to Drive Strategic Renewal, HBS Press, Boston.

TENNANT, C.; WARWOOD, S. J.; CHIANG, M. M. P. (2002) A continuous improvement process at Severn Trent Water, The TQM Magazine, v. 14, n. 5, p. 284-292. DOI: $10.1108 / 09544780210439716$

TOMA, S. G.; MARINESCU, P. (2013) Global Strategy: the Case of Nissan Motor Company, proceedings of International Economic Conference of Sibiu 2013 Post Crisis Economy: Challenges and Op.ortunities, Sibiu, v. 6, p. 418-423.

THOMAZ, M. F. (2015) Balanced Scorecard e Hoshin Kanri - Alinhamento Organizacional e Execução Estratégica. Lidel. Lisboa.

YANG, C. C.; YEHB, T. M. (2009) An integrated implementation model of strategic planning, BSC and Hoshin management, Total Quality Management, v. 20, n. 9, p. 9891002.

WITCHER, B. J.; BUTTERWORTH, R. (1999) Hoshin Kanri: How Xerox Manages, Long Range Planning, v. 32, n. 3, p. 323-332.

WITCHER, B.; BUTTERWORTH, R. (2001) Realising the vision: Translating Strategy into action throught Policy Management. Journal of the Institution of British

Telecomunication Engenieers, part 3.

WITCHER, B. J. (2003) Policy management of strategy, Strategic Change, v.12, p. 83-94.

WITCHER, B. J.; CHAU, V. S. (2007) Balanced Scorecard and Hoshin Kanri: dynamic capabilities for managing strategic fit. Management Decision, v. 45, n. 3, p. 518-538. 